\title{
To Study Physical Properties of Self Compacting Concrete
}

\author{
Devvratvedanand Kumar ${ }^{1}$, Brijesh Lopes ${ }^{2}$, Kunal Mhatre ${ }^{3}$, Rohit Nityanand ${ }^{4}$, \\ Shreeshail Heggond ${ }^{5}$ \\ ${ }^{1234}$ (UG Students), ${ }^{5}$ Associate Professor, \\ Department of Civil Engineering St John College of Engineering and Management, palghar
}

DOI: 10.46335/IJIES.2020.5.6.7

\begin{abstract}
Concrete is one of the versatile construction materials which are used worldwide. Self-compacting Concrete is a type of concrete which is capable of flowing into the form work uniformly under its own weight, without segregation and bleeding, better finishes, easier placement, thinner concrete sections, no vibration, safer working environment without any application of vibration. Due to many advantages like faster construction, reduction in site for thinner concrete sections, improved durability, concrete. This study mainly focuses on the self-compacting concrete which is prepared by partially replacing cement with industrial by-products. To understand the behavior of the selfcompacting concrete, the fresh properties along with the durability characteristics have been discussed.
\end{abstract}

\section{I- INTRODUCTION}

S lf-compacting concrete (SCC), also known as selfconsolidating concrete, is one of the most widely used concrete types, mainly because of its self-compacting characteristics and strength. SCC is a highly flowable, non-segregating, special concrete type that can settle into formworks, and encapsulates, heavily reinforced, narrow and deep sections by means of its own weight. Unlike conventional concrete, SCC does not require compaction using external force from mechanical equipment such as immersion vibrators. In addition to these attractive benefits, as a high-performance concrete SCC maintains all of concrete's common mechanical and durability characteristics. SCC was developed in Japan in 1980s in order to achieve high-performance durable concrete structures, and with advancements in concrete technology its use has become widespread all over the world (Ozawa et al., 1989; Okamura and Ouchi, 2003). The advantages of SCC in its fresh and hardened states include economic efficiency (i.e. it shortens the construction time as well as it reducing the labour and equipment required), improvement in working and living environment (i.e. it may consume high amount of industrial by-products, it reduces construction noise and health hazards) and enhancement in automation of the construction process (Ozawa et al., 1995; Bartos and Cechura, 2001). Generally, SCC is used for constructing reinforced concrete elements with closely arranged reinforcement sections, construction elements with limited compaction possibilities, filigree construction elements, exposed concrete parts where high surface quality is required, texture surfaced concrete construction elements, and reinforced concrete parts in environmentally noise sensitive sites.

Compared with ordinary concrete, SCC includes large amounts of binder, superplasticizer, and/or viscosity modifying admixtures (VMA). The supplemented binder content is associated with SCMs such as fly ash (FA), ground-granulated blast furnace slag (GGBFS), silica fume (SF), metakaolin (MK), rice husk ash (RHA), etc. The incorporation of SCMs into cement or concrete mixes provides many benefits to fresh and hardened concrete, such as improvement in workability and ultimate strength values. It also reduces the construction cost. SCC with high-volume SCMs is defined by the replacement of large amount of SCMs with cement in $\mathrm{SCC}$ mixes. 


\section{II- MATERIALS}

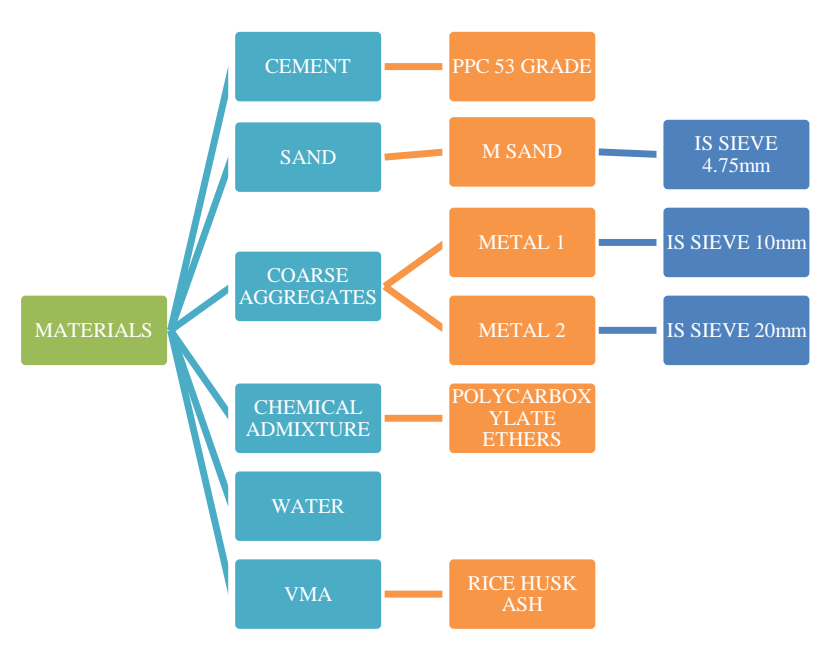

Fig.1-Materials used

Cement -

Ultra-tech PPC 53 grade used in this work and properties of material is mentioned in table 1 .

Table 1- Cement Physical Properties

\begin{tabular}{|c|c|}
\hline Properties of Cement & $\begin{array}{c}\text { Experimental values } \\
\text { obtained }\end{array}$ \\
\hline Initial Setting Time (min) & 40 \\
\hline Final Setting Time (min) & 340 \\
\hline Normal Consistency (\%) & 26.35 \\
\hline Specific Gravity & 3.157 \\
\hline Fineness & 7 \\
\hline $\begin{array}{c}\text { Cement Compressive } \\
\text { strength at } 28^{\text {th }} \text { day }\end{array}$ & $53.8\left(\mathrm{~N} / \mathrm{mm}^{2}\right)$ \\
\hline
\end{tabular}

Fine Aggregates -

In this work, crushed stone sand i.e. M-sand belongs to Zone II. Laboratory test results are mentioned in table 2 .

Table 2-M-Sand Physical Properties

\begin{tabular}{|c|c|}
\hline Properties of M-sand & $\begin{array}{c}\text { Experimental Value } \\
\text { Obtained }\end{array}$ \\
\hline Specific Gravity & 2.76 \\
\hline Bulk Density & $1717 \mathrm{~kg} / \mathrm{m}^{3}$ \\
\hline Fineness modulus & 2.71 \\
\hline Water Absorption & $1.6 \%$ \\
\hline
\end{tabular}

Coarse Aggregates-

Here there are two type of aggregates are used.

1) Metal 1: In which they are angular in shape and $10 \mathrm{~mm}$ IS sieve down size.

2) Metal 2: In which they are angular in shape and 20mm IS sieve down size.

Physical properties of coarse aggregates are mentioned in table 3 .

Table 3-Coarse Aggregates physical properties

\begin{tabular}{|c|c|}
\hline $\begin{array}{c}\text { Properties of Coarse } \\
\text { Aggregates }\end{array}$ & $\begin{array}{c}\text { Experimental Values } \\
\text { Obtained }\end{array}$ \\
\hline Specific Gravity & 2.88 \\
\hline Impact Value & $18.6 \%$ \\
\hline $\begin{array}{c}\text { Los Angeles abrasion } \\
\text { value }\end{array}$ & $25.46 \%$ \\
\hline Combined Index & $27.52 \%$ \\
\hline Water absorption & $0.5 \%$ \\
\hline Fineness Modulus & 7.46 \\
\hline
\end{tabular}

Super plasticizer-

Chemical namely Polycarboxylate ethers was used. Properties of Polycarboxylate ether is mentioned in table 4.

Table 4- Properties of Polycarboxylate ethers.

\begin{tabular}{|c|c|}
\hline Items & $\begin{array}{c}\text { Specification (FXP 50 } \\
\%)\end{array}$ \\
\hline Visual Appearance & $\begin{array}{c}\text { Pale Brown Viscous } \\
\text { liquid }\end{array}$ \\
\hline$\left(23^{\circ} \mathrm{C}\right)$ Density & $1.10 \pm 0.02$ \\
\hline $\mathrm{PH}\left(23^{\circ} \mathrm{C}\right)$ Acidity & $5.0 \pm 0.5$ \\
\hline$(\%)$ Solid Content & $40.0 \pm 2.0$ \\
\hline$\left(0^{\circ} \mathrm{C}, 24\right.$ hours $)$ Stability & No Crystallization \\
\hline Solid Content $(w t . \%)$ & $50 \pm 2$ \\
\hline Appearance & Brown Viscous Clear \\
& liquid \\
\hline
\end{tabular}

Water-

Water must be free from all chemical and physical impurities as such that it deemed to be a drinking water. The $\mathrm{pH}$ value of water used in this work is 6.5.

viscosity modifying admixtures-

Rice husk ash of $10 \%$ Cementitious material was used. 


\section{III- MIX PROPORTION}

Two conventional and three SCC mixes with chemical replacement is prepared and examined to determine the properties of self- compacting concrete. Table 5 and 6 represents the Mix Proportion of conventional concrete and self-compacting concrete mixtures.

Table 5- Mix Proportions for Conventional Concrete

\begin{tabular}{|l|l|l|}
\hline & $\begin{array}{l}\text { Conventional } \\
\text { Concrete Trail 1 }\end{array}$ & $\begin{array}{l}\text { Conventional } \\
\text { Concrete Trail 2 }\end{array}$ \\
\hline Cement & $472.90 \mathrm{~kg} / \mathrm{m}^{3}$ & $655 \mathrm{~kg} / \mathrm{m}^{3}$ \\
\hline $\begin{array}{l}\text { Fine } \\
\text { Aggregates }\end{array}$ & $743.66 \mathrm{~kg} / \mathrm{m}^{3}$ & $549.83 \mathrm{~kg} / \mathrm{m}^{3}$ \\
\hline $\begin{array}{l}\text { Coarse } \\
\text { Aggregates }\end{array}$ & $1010.25 \mathrm{~kg} / \mathrm{m}^{3}$ & $1104 \mathrm{~kg} / \mathrm{m}^{3}$ \\
\hline Water & $189.162 \mathrm{~kg} / \mathrm{m}^{3}$ & $203 \mathrm{~kg} / \mathrm{m}^{3}$ \\
\hline Chemical & - & - \\
\hline $\begin{array}{l}\text { Rice Husk } \\
\text { Ash }\end{array}$ & - & - \\
\hline
\end{tabular}

Table 6- Mix Proportions for SCC

\begin{tabular}{|c|c|c|c|}
\hline Materials & $\begin{array}{c}\text { SCC 1\% } \\
\text { PCE }\end{array}$ & $\begin{array}{c}\text { SCC } \\
0.75 \% \\
\text { PCE }\end{array}$ & $\begin{array}{c}\text { SCC 0.5\% } \\
\text { PCE }\end{array}$ \\
\hline Cement & $\begin{array}{c}452.25 \\
\mathrm{~kg} / \mathrm{m}^{3}\end{array}$ & $\begin{array}{c}495.324 \\
\mathrm{~kg} / \mathrm{m}^{3}\end{array}$ & $542.7 \mathrm{~kg} / \mathrm{m}^{3}$ \\
\hline Fine & 1085.86 & 997.488 & 951.98 \\
Aggregates & $\mathrm{kg} / \mathrm{m}^{3}$ & $\mathrm{~kg} / \mathrm{m}^{3}$ & $\mathrm{~kg} / \mathrm{m}^{3}$ \\
\hline Coarse & 888.43 & 851.60 & 812.76 \\
Aggregates & $\mathrm{kg} / \mathrm{m}^{3}$ & $\mathrm{~kg} / \mathrm{m}^{3}$ & $\mathrm{~kg} / \mathrm{m}^{3}$ \\
\hline Water & 140.7 & 154.1 & 168.84 \\
& $\mathrm{~kg} / \mathrm{m}^{3}$ & $\mathrm{~kg} / \mathrm{m}^{3}$ & $\mathrm{~kg} / \mathrm{m}^{3}$ \\
\hline Chemical & $5.02 \mathrm{~kg} / \mathrm{m}^{3}$ & 4.128 & 3.0115 \\
& & $\mathrm{~kg} / \mathrm{m}^{3}$ & $\mathrm{~kg} / \mathrm{m}^{3}$ \\
\hline Rice Husk & 50.25 & 55.036 & $60.3 \mathrm{~kg} / \mathrm{m}^{3}$ \\
Ash & $\mathrm{kg} / \mathrm{m}^{3}$ & $\mathrm{~kg} / \mathrm{m}^{3}$ & \\
\hline
\end{tabular}

Rice husk ash is used as a viscosity modifying agent.

Ratio of coarse and fine aggregates is taken as, 55\% of fine aggregates and $45 \%$ of coarse aggregates of total aggregates respectively.

Ratio of coarse aggregates is taken as $60 \%$ of $10 \mathrm{~mm}$ and $40 \%$ of $20 \mathrm{~mm}$ of total coarse aggregate respectively.

Water is reduced by $33 \%$ because of use of PCE.

\section{IV- RESULT AND DISCUSSION}

In this study, fresh, hardened properties and durability of self-compacting concrete were investigated by using waste materials (Rice Husk Ash). The investigations were carried out according to appropriate criteria given by European standards. In the present study, such properties of self-compacting concrete produced with fly ash were investigated based on fresh concrete tests, specifically workability, strength and durability tests.

\section{Fresh Properties}

\section{Slump Flow Test}

The slump value plays a major role in SCC. By the value of slump, it is possible to know the effectiveness of flow in SCC; i.e., flowability of SCC under congested reinforcements can be studied at site through this test. The slump values also determine the durability of the mix, segregation and bleeding in the mix. The minimum value of slump is to be $650 \mathrm{~mm}$ and the maximum value $800 \mathrm{~mm}$ for a fresh SCC. The slump values for different mixes are shown in table. 7 and fig. 2

Table 7- Slump Flow test

\begin{tabular}{|c|c|}
\hline Mix Proportions (\%) & Slump Flow \\
\hline SCC $1 \%$ PCE & $760 \mathrm{~mm}$ \\
\hline SCC $0.75 \%$ PCE & $705 \mathrm{~mm}$ \\
\hline SCC $0.5 \%$ PCE & $676 \mathrm{~mm}$ \\
\hline
\end{tabular}

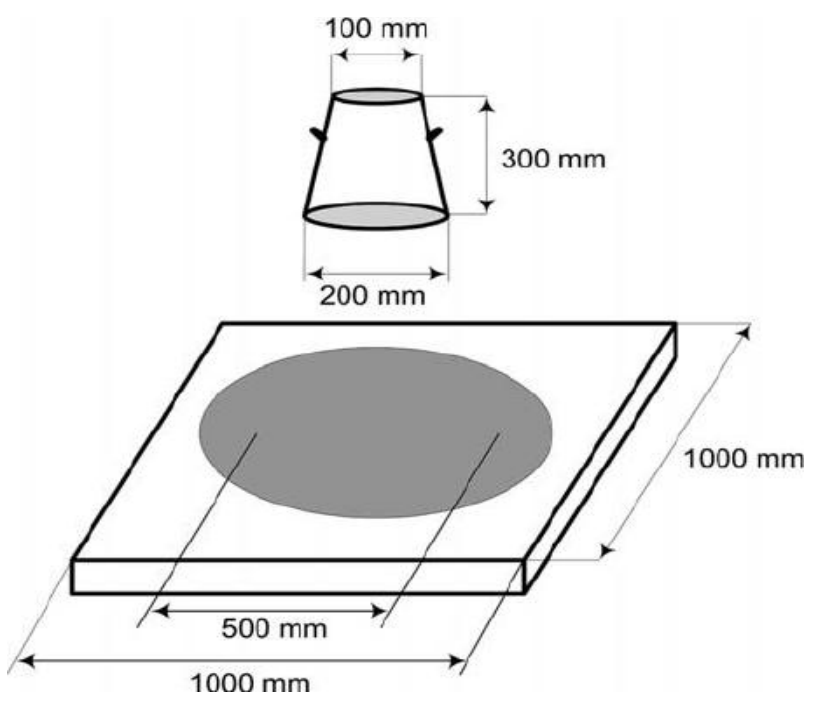

Fig 2- Apparatus of slump cone test 
International Journal of Innovations in Engineering and Science, Vol 5, No.6, 2020 $w w w . i j i e s . n e t$

Table 8- L-Box Test

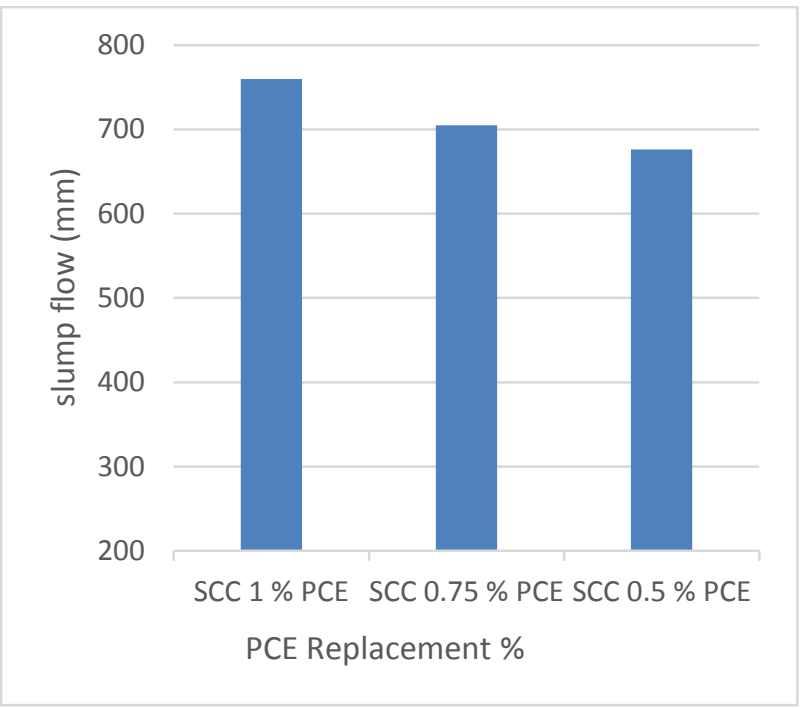

Fig 3-Slump flow test with PCE

\section{L- Box Test}

The ratio of is used to indicate the value of the result of L-box. The minimum value of can be 0.8 and the maximum value 1.0 .

The passing ability of the concrete is tested and concludes that with increase in chemical admixture (PCE) the passing ability increases. In this mix, $1 \%$ replacement by polycarboxylate ether behaves better in passing ability of concrete. The passing ability of L-Box test is shown is table.8

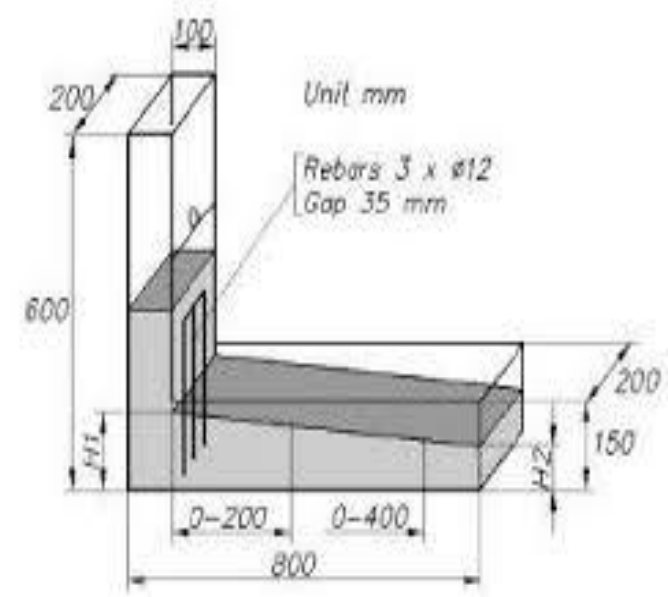

Fig 4 - Apparatus of L-Box test

\begin{tabular}{|c|c|}
\hline Mix Proportion (\%) & h2/h1 \\
\hline SCC 1 \% PCE & 0.91 \\
\hline SCC $0.75 \%$ PCE & 0.818 \\
\hline SCC $0.5 \%$ PCE & 0.724 \\
\hline
\end{tabular}

Mechanical Properties

Compressive strength can be determined by the compression test. Here the cube of $150 \mathrm{~mm}^{3}$ dimension is casted for testing, the mean average strength value for the three cube $(3,7,28$ days) specimens are considered. The compressive strength results are mentioned in the table. 9 and fig. 5

The strength attainment of SCC $1 \%$ PCE, SCC $0.75 \%$ PCE, and SCC $0.5 \%$ PCE, was $58.75 \%, 57.27 \%$, and $54.33 \%$ respectively on 3 days, $69.38 \%, 75.72 \%$, and $71.19 \%$ on 14 days and $121.16 \%, 125.33 \%$, and $117.58 \%$ on 28 days.

When compared with the conventional concrete increasing amounts of chemical admixtures generally increase the strength.

In this mix, $0.75 \%$ replacement by polycarboxylate ether behaves better in respect to mechanical properties of concrete.

Table.9- Compressive Strength

\begin{tabular}{|c|c|c|c|}
\hline \multirow{2}{*}{ Sample } & $\begin{array}{c}\text { Compressi } \\
\text { ve strength } \\
\left(\mathbf{N} / \mathbf{m m}^{2}\right)\end{array}$ & $\begin{array}{c}\text { Compressi } \\
\text { ve strength } \\
\left(\mathbf{N} / \mathbf{m m}^{\mathbf{2}}\right)\end{array}$ & $\begin{array}{c}\text { Compressi } \\
\text { ve strength } \\
\left(\mathbf{N} / \mathbf{m m}^{\mathbf{2}}\right)\end{array}$ \\
\cline { 2 - 4 } & $\mathbf{3}$ days & $\mathbf{7}$ days & $\mathbf{2 8 ~ d a y s}$ \\
\hline $\begin{array}{c}\text { Convention } \\
\text { al Trail 1 }\end{array}$ & 12.93 & 18.12 & 36.46 \\
\hline $\begin{array}{c}\text { Convention } \\
\text { al Trail 2 }\end{array}$ & 26.86 & 39.39 & 60.28 \\
\hline $\begin{array}{c}\text { SCC 1\% } \\
\text { PCE }\end{array}$ & 32.31 & 38.71 & 66.64 \\
\hline $\begin{array}{c}\text { SCC 0.75\% } \\
\text { PCE }\end{array}$ & 31.49 & 41.65 & 68.93 \\
\hline $\begin{array}{c}\text { SCC 0.5\% } \\
\text { PCE }\end{array}$ & 29.88 & 39.16 & 64.67 \\
\hline
\end{tabular}




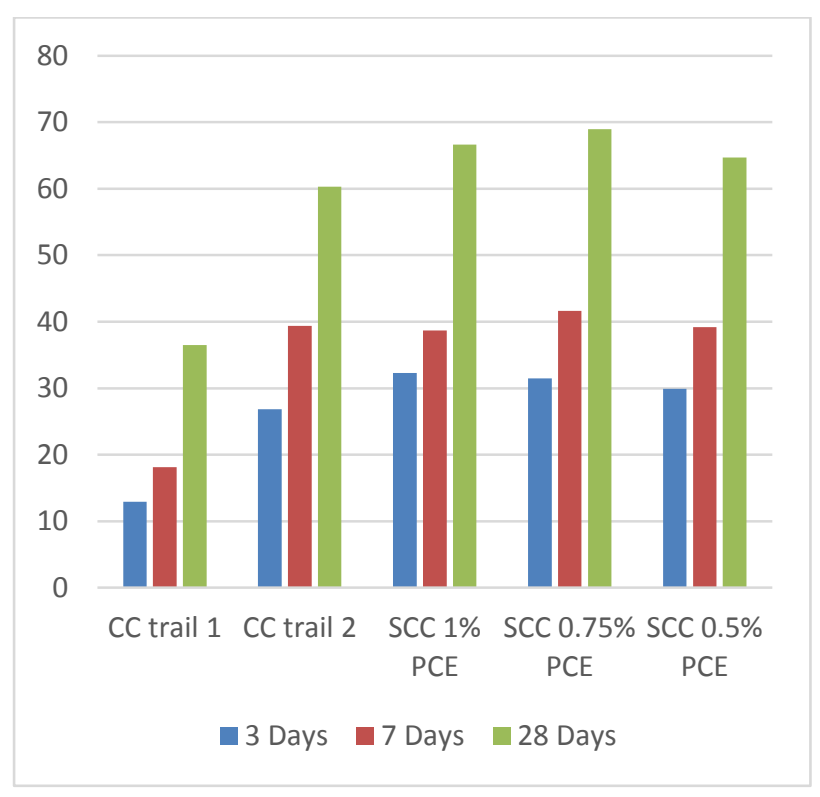

Fig.5- Comparison of CC and SCC

\section{V- CONCLUSION}

- In present scenario there is a greater need for selfcompacting concrete due to sickness of member \& architectural requirement, also to improve durability of the structure.

- Use of $0.75 \%$ of polycarboxylate ether (of Cementitious material) gives better result.

- Now the world is going to facing greater need of high performance concrete, durability point of view and SCC where the conventional way of compacting may not be always useful under different site condition.so instead of going for the conventional let us mix the concrete compacting on its own which is called as self-compacting concrete.

- Use of rice husk ash (wastage material) reduce $10 \%$ cement content in concrete.

- At same grade of concrete, we find SCC with certain change as decrease of $10 \%$ of final cost (electricity cost, labour cost, reduction in cement due to use of rice husk ash).

\section{REFERENCES}

[1] EFNARC. 2005. European guidelines for self-compacting concrete, specification, production and use. May.

[2] Baoguo, Ma and Huixian, Wang. 2011. Effect of viscosity modifying admixture on the workability of selfcompacting concrete, Advanced Material Research, 306307: 946- 950

[3] H. J. H. Brouwers and H. J. Radix, "Self-compacting concrete: Theoretical and experimental study," Cement and Concrete Research, vol. 35, no. 11, pp. 2116-2136, 2005.

[4] Seung Hee Kwon, Yilmaz Akkaya, Surendra P. Shah, "Cracking of fiber reinforced SCC due to restrained shrinkage" International Journal of Concrete Structure and Material (2007)

[5] Hommer H, Interaction of polycarboxylate ether with silica fume, Journal of the European Ceramic Society Vol. 29, 2009, No. 10, pp. 1847-1853.

[6] P. L. Domone, "Self-compacting concrete: An analysis of 11 years of case studies," Cement and Concrete Composites, vol. 28, no. 2, pp. 197-208, 2006.

[7] R.N.Uma, C.V Saranya Naryanan, "A review on performance of self-compacting concrete Using mineral and chemical admixture" International Journal of Engineering Research and Modern Education(2017)

[8] EFNARC, Specifications and Guidelines for Selfcompacting Concrete, Association House, Surrey, UK, 2002.

[9] S Arunchaitanya, E Arunakanthi, "Usage of Mineral Admixtures in Self Compacting Concrete" International Journal of Innovative Technology and Exploring Engineering (2019)

[10] Sholihin as'ad, Purnawan gunawan, M. Syarif alaydrus, "Fresh State Behavior of Self Compacting Concrete Containing Waste Material Fibres" 